\title{
Measuring Research Productivity of Centre with Potential for Excellence in Particular Area (CPEPA) status in Karnataka state
}

\author{
Mallikarjun Kappi ${ }^{1}$, Chaman Sab M², Balabhim Sankrappa Biradar ${ }^{3}$ \\ 1, 3 Kuvempu University \\ India \\ \{mkmallikarjun@gmail.com, bsbiradar53@rediffmail.com\} \\ ${ }^{2}$ S.B.C. First Grade College for Women \\ Athani P.G. Centre Davanagere \\ India \\ \{chamansabm@gmail.com\}
}

\begin{abstract}
This study measuring the research productivity of centre with potential for Excellence in Particular Area (CPEPA), status in Karnataka state. The research publication data, indexed in SCOPUS database for the three Institutions for 10 years (2010 - 2019) are used for analysis. The parameters such as from-wise, year-wise, subject-wise classification of published papers, most productive authors, and the most preformed journals and citation impact and discipline -wise research strength of these three institutions. Measuring research productivity of the centre with potential for excellence in Particular Area (CPEPA) is measured and compared with three institutions such as Karnatak University, Dharwad, Bangalore University, Bangalore and University of Mysore, Mysore. Nowadays, the workflow of bibliometrics study has been automated because of the uses of software packages like (Bibliometrix R Package, Bib excel, VOSviewer, etc.) for automated bibliometrics workflow. In this article, we propose to utilize an open-source and exclusive tool, developed and produced in $R$ language, for classic and logical bibliometrics study. For creating and visualizing a bibliometric network between author, sources, keywords, and publications we used VOSviewer software.
\end{abstract}

Keywords: Centre with Potential for Excellence in Particular Area, CPEPA, UGC, Measuring research, Research Productivity, Scopus, Scientometrics

DOI: https://doi.org/10.6025/stm/2020/2/43-58

\section{Introduction}

The idea of 'excellence' is entrenched in many areas of activity, and the term is used commonly to refer to extremely good or magnificent. In higher education, it implies various things in various contexts. Excellence might be connected with the status and standing of institutions, but much relies upon the view of student knowledge and the differing missions of institutions. It is easy to explain, it relates to academic quality and standards, where excellence identifies with the quality of teaching, the competencies of students, the scale of resource provision, and the level of student success.

All the first world countries understood the significance of the link between higher education, research, and development well as expected and made fundamental activities and strides for fortifying this sector. Across the Globe, universities are measured as places where education, research, and development happen. Hence, appropriate higher education and research set-up are now essential for the improvement and progress of a nation. In India as of October 2020, 958 universities are delivering to the higher education needs of the country. These include 54 Central universities (CUs), 416 State Universities, 124 Deemed to be universities, and 364 private universities. Of these 958 universities, 12 universities were selected under the scheme Centre with Potential for Excellence in Particular Area (CPEPA). The University Grants Commission (UGC) has been empowering well-performing colleges and universities in the nation to strive for excellence in their chosen areas of academic and research work.

The UGC (UGC CPEPA12, 2011) has conferred the status of Universities with Potential for Excellence to 12 Universities (as of 18th October 2011). UGC eligibility criteria laid down in the XI Plan Guidelines on CPEPA, 12 universities were selected, viz., Karnataka University, Dharwad, Karnataka; Bangalore University, Bangalore, Karnataka; Guru Nanak Dev University, Amritsar, 
Punjab; JaiNarayan Vyas University, Jodhpur, Rajesthan; University of Madras, Tamil Nadu ("Development of Drugs from Medicinal Plants for Human Welfare); Annamalai University, Annamalainagar, Tamil Nadu; University of Calcutta, Kolkata, West Bengal; Punjab University, Chandigarh (Cultural Fixation on "Honour": A Gender Audit of Punjab and Haryana); Osmania University, Hyderabad, Andhra Pradesh; University of Madras, Chennai, Tamil Nadu (Climate Change and its impact on mangrove ecosystem in the region); Punjab University, Chandigarh (Application of Nanomaterials, Nanoparticles and Nanocomposites) and University of Mysore, Mysore, Karnataka. The current study was confined to three CPEPA's of Karnataka and identified how the institutions are performing in various fields of research and development.

Karnataka University, Dharwad; Bangalore University, Bangalore and University of Mysore, Mysore are the highly reputed universities of Karnataka. These CPEPA's identified by National Institutional Ranking Framework (NIRF) 2020, MHRD, Government of India's ranked $68^{\text {th }}$ and $27^{\text {th }}$ unfortunately, Karnataka University, Dharwad didn't get placed in top 100 and these universities appear with a good rank in world's ranking of various academic ranking agencies.

\section{Literature Review}

Over the year's various bibliometric studies/ scientometric studies has been accomplished to evaluate the research productivity of an organization, country, subject, author, sources, etc. Essential factors have been identified, the complexity of variance defined and remedies were recommended to overcome. These studies have proven a mirror to the researchers and policymakers in formulating the future road map.

(GN Gourikeremath et al., 2015; Gouri Gourikeremath \& Hiremath, 2020) performed comparative assessments of scientific research output of science faculties of University of Mysore and the Karnatak University, and Scientific Productivity of Universities with Potential for Excellence (UPE) status in India using different bibliometric indicators, by using Web of Science database during 2002-16 and 1999-2014 respectively. (Kappi et al., 2020; S. Kumar \& Senthilkumar, 2019) examined the research performance of India's NIRF first ranked institute, Indian Institute of Science (IISc), Bangalore during 2014-2018 using WoS database and Research Productivity of NIRF 2020 Top Indian Law Institutions during 2009 - 2019 using SCOPUS database. (Kappi, 2019) evaluated the scientific research output of the Kuvempu University using different bibliometric indicators during 1990-2019 based on the Web of Science database. (A. Kumar et al., 2019) examined the growth of publication in the different subject categories, the impact of growth before and after NIRF. The sample data is considered for 20 universities from the top 25 top universities ranked last three years in NIRF using the Web of Science database for the period $2014-2016$. (Utama et al., 2019) studied research productivity of Diponegoro University, Indonesia by using various bibliometric tools during 2014 - 2018 by using the SCOPUS database.

(Prathap \& Gupta, 2009) studied the top 30 Indian engineering and technological institutions found on their research production during 1999-2008. (Prathap, 2014) assessed the research productivity of institutions associating to the higher education sector for the period 2003-2011. (Basu et al., 2016) evaluated the research productivity of the central institutions in India during 2010 - 2014. (Solanki et al., 2016) done a scientometric study of the research productivity of IISER for the period 20102014. (Rajan et al., 2018) examined the research output of Indian institutions for the period 2011-2016 based on data gained from the SciVal bibliometric tool. (Das, 2019; Prathap, 2013) assessed the research output of the IITs in India by using Web of Science (WoS) and SCOPUS databases. (Prathap \& Sriram, 2017) (Prathap \& Sriram, 2017) likened the research quality and socio-economic output of private institutions in India with IISc by using bibliometric and fiscal data from NIRF 2017. (Marisha et al., 2017) studied the research output of the 39 central universities in India using Wos database. (Banshal et al., 2018) done bibliometric study of the research output of the NIT's in India for the period 2005-2016. (Sharma et al., 2019) during 20082017 studied the research output of Indian institutions in biotechnology research. (Sangam \& Bagalkoti, 2015) assessed and measured the growth of publications of the National Assessment and Accreditation Council (NAAC) accredited universities in India during 2001-2010 using the SCOPUS database.

\section{Objectives}

The main objective of the study to find out and evaluate the research output of Centre with Potential for Excellence in Particular Area (CPEPA) status in India, restricted to Karnataka state universities viz. Karnatak University, Dharwad; Bengalore University, Bengalore and University of Mysore, Mysore. The specific objectives are as follows:

- To analyse year-wise research output and CPEPA's research output.

- To identify different type of channels used for communicating

- To know the most preferred subject/research area.

- To identify the most productive authors. 
- To know the most productive sources.

- To identify the most used keywords.

\section{Methodology}

The data was collected by searching the SCOPUS database from 2010 to 2019 and compare the research performance of Karnataka state CPEPA Universities. The advanced search option of SCOPUS database has been chosen ((AFFILCOUNTRY(India) AND AF-ID (“Karnatak University” 60029908) OR AF-ID("Bangalore University” 60009220) OR AFID(“University of Mysore” 60013290)) AND (LIMIT-TO (PUBYEAR,2019) OR LIMIT-TO (PUBYEAR,2018) OR LIMIT-TO (PUBYEAR, 2017) OR LIMIT-TO (PUBYEAR, 2016) OR LIMIT-TO (PUBYEAR, 2015) OR LIMIT-TO (PUBYEAR, 2014) OR LIMIT-TO (PUBYEAR,2013) OR LIMIT-TO (PUBYEAR, 2012) OR LIMIT-TO (PUBYEAR, 2011) OR LIMIT-TO ( PUBYEAR, 2010))). The mentioned affiliations ID has been considered and all the associated papers are extracted, retrieved, collected, and analysed with Excel, VOSviewer (van Eck \& Waltman, 2010), and R (Aria \& Cuccurullo, 2017) package. A total of 8,953 records were retrieved on $1^{\text {st }}$ October 2020 for respective Karnataka state CPEPA Universities. Further, the study uses VOS viewer software and the $\mathrm{R}$ Bibliometrix package for visualization network.

\section{Bibliometrics Indicators}

Some of the Research output indicators are used to analyse the collected data, based on the SCOPUS database.

\section{Participative Index (Pal)}

To evaluate the performance level of research of an institution, an index called 'Participative Index (Pal)' has been designed (García-García et al., 2005). Pal is the ratio of the number of papers generated in a country or institution and the total number of documents collected in this repertoire. This will be expressed as:

$$
P a I=\frac{\text { Number of papers generated in an institution }}{\text { Total number of documents collected in this repertoire }} \times 100
$$

\section{Results and Discussions}

\subsection{Year-wise Distribution of Publications}

Table 1 and Figure 1 highlights the year-wise distribution of publications, h-index, mean TCPA, and citations received for

Table 1. Year wise distribution of publications

\begin{tabular}{|l|l|l|l|l|l|l|}
\hline Year & Publications & TC & ACPP & h-index & $\begin{array}{c}\text { Mean } \\
\text { TCPA }\end{array}$ & $\begin{array}{c}\text { Mean } \\
\text { TCPY }\end{array}$ \\
\hline 2010 & 875 & 218 & 0.249 & 45 & 12.749 & 1.275 \\
2011 & 1005 & 1247 & 1.241 & 47 & 11.812 & 1.312 \\
2012 & 906 & 2399 & 2.648 & 38 & 8.921 & 1.115 \\
2013 & 952 & 3554 & 3.733 & 34 & 7.879 & 1.126 \\
2014 & 917 & 4915 & 5.36 & 37 & 8.462 & 1.41 \\
2015 & 827 & 5998 & 7.253 & 32 & 7.045 & 1.409 \\
2016 & 855 & 7072 & 8.271 & 29 & 6.692 & 1.673 \\
2017 & 803 & 8517 & 10.606 & 27 & 6.306 & 2.102 \\
2018 & 898 & 10507 & 11.7 & 23 & 4.601 & 2.301 \\
2019 & 915 & 12393 & 13.544 & 18 & 2.223 & 2.223 \\
\hline
\end{tabular}

TC=Total Citations, $A C P P=$ Average Citation per Publication, $T C P A=$ Total Citations per Article, TCPY= Total Citations per Year 
CPEPA of Karnataka State. A total of 8, 953 papers were published by these three CPEPA's and is found that the most productive year in terms of publication count is 2011 with 1005 publications and 1247 citations, followed by 952 publications with 3554 citations and ACPP 3.733 published in 2013, 917 papers were published in the year 2014, and 915 papers were published in the year 2019 and has got highest citations with 12393 . The lowest number of articles i.e., 803 were published in the year 2017. The h-index, Mean TCPA, and the Mean TCPY are shown in Table 1.

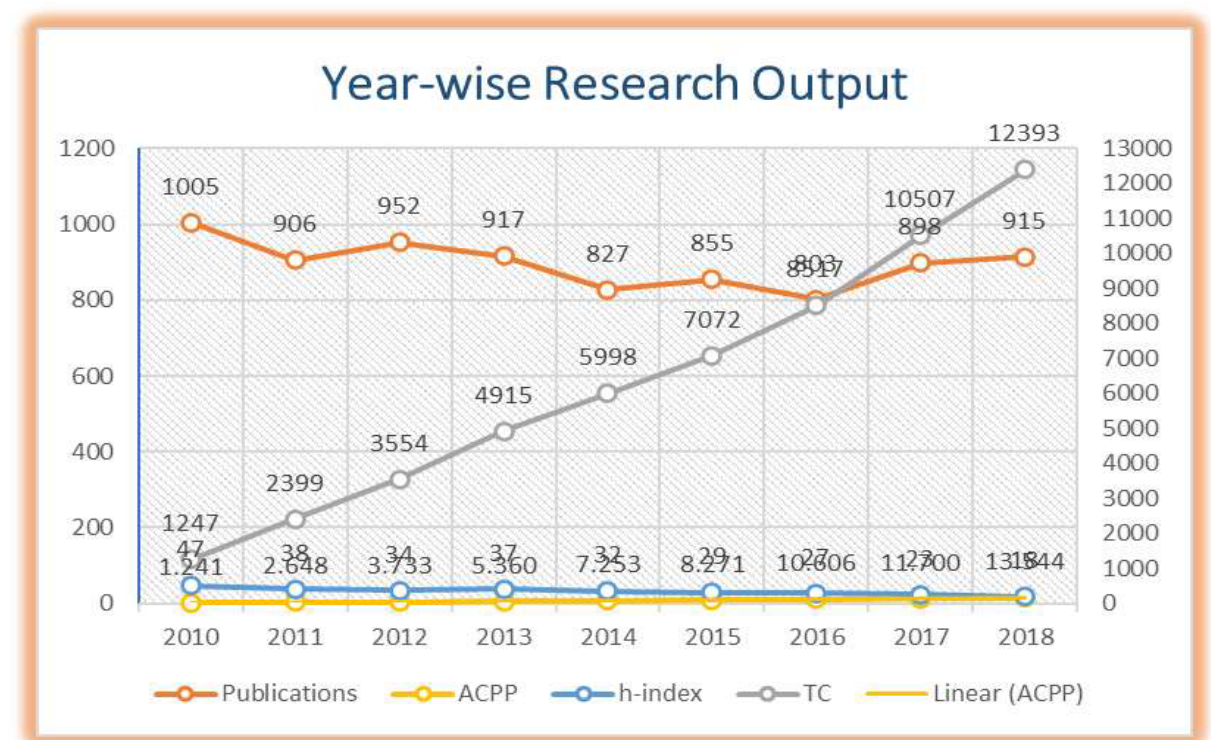

Figure 1. Year wise distribution of publications

\subsection{University wise Distribution of Publications}

University of Mysore, Mysore has contributed 4330 publications with 47.183 of Pal and placed first, followed by Bangalore University, Bangalore contributed 2660 publications with 28.996 of Pal and Karnatak University, Dharwad contributed 2186 publications with 23.820 of Pal. During the study period, University of Mysore (UMM), Mysore published the highest publications 4330 with 24066 citations of papers closely followed by Bangalore University (BUB), Bangalore 2661 with 19306 citations of the papers. The lowest number of papers was published by Karnatak University (KUD), Dharwad 2186 with 15463 of the

Table 2. Publications pattern of three CPEPA Institutions

\begin{tabular}{|l|llll|lllll|llll|}
\hline \multirow{2}{*}{ Year } & \multicolumn{3}{|c}{ KUD } & \multicolumn{3}{c|}{ BUB } & \multicolumn{4}{c|}{ UMM } \\
\cline { 2 - 11 } & TP & TC & ACPP & PoI & TP & TC & ACPP & PoI & TP & TC & ACP & PoI \\
\hline 2010 & 213 & 59 & 0.277 & 2.321 & 238 & 69 & 0.290 & 2.593 & 443 & 96 & 0.217 & 4.827 \\
2011 & 214 & 337 & 1.575 & 2.332 & 317 & 384 & 1.211 & 3.454 & 496 & 540 & 1.089 & 5.405 \\
2012 & 199 & 649 & 3.261 & 2.168 & 273 & 836 & 3.062 & 2.975 & 456 & 958 & 2.101 & 4.969 \\
2013 & 182 & 938 & 5.154 & 1.983 & 293 & 1262 & 4.307 & 3.193 & 502 & 1401 & 2.791 & 5.470 \\
2014 & 225 & 1284 & 5.707 & 2.452 & 251 & 1785 & 7.112 & 2.735 & 466 & 1953 & 4.191 & 5.078 \\
2015 & 234 & 1533 & 6.551 & 2.550 & 208 & 2148 & 10.327 & 2.267 & 421 & 2542 & 6.038 & 4.588 \\
2016 & 226 & 1839 & 8.137 & 2.463 & 242 & 2472 & 10.215 & 2.637 & 407 & 3058 & 7.514 & 4.435 \\
2017 & 205 & 2327 & 11.351 & 2.234 & 224 & 2889 & 12.897 & 2.441 & 392 & 3573 & 9.115 & 4.272 \\
2018 & 248 & 2963 & 11.948 & 2.702 & 290 & 3482 & 12.007 & 3.160 & 381 & 4532 & 11.895 & 4.152 \\
2019 & 240 & 3534 & 14.725 & 2.615 & 325 & 3979 & 12.243 & 3.541 & 366 & 5413 & 14.79 & 3.988 \\
\hline
\end{tabular}




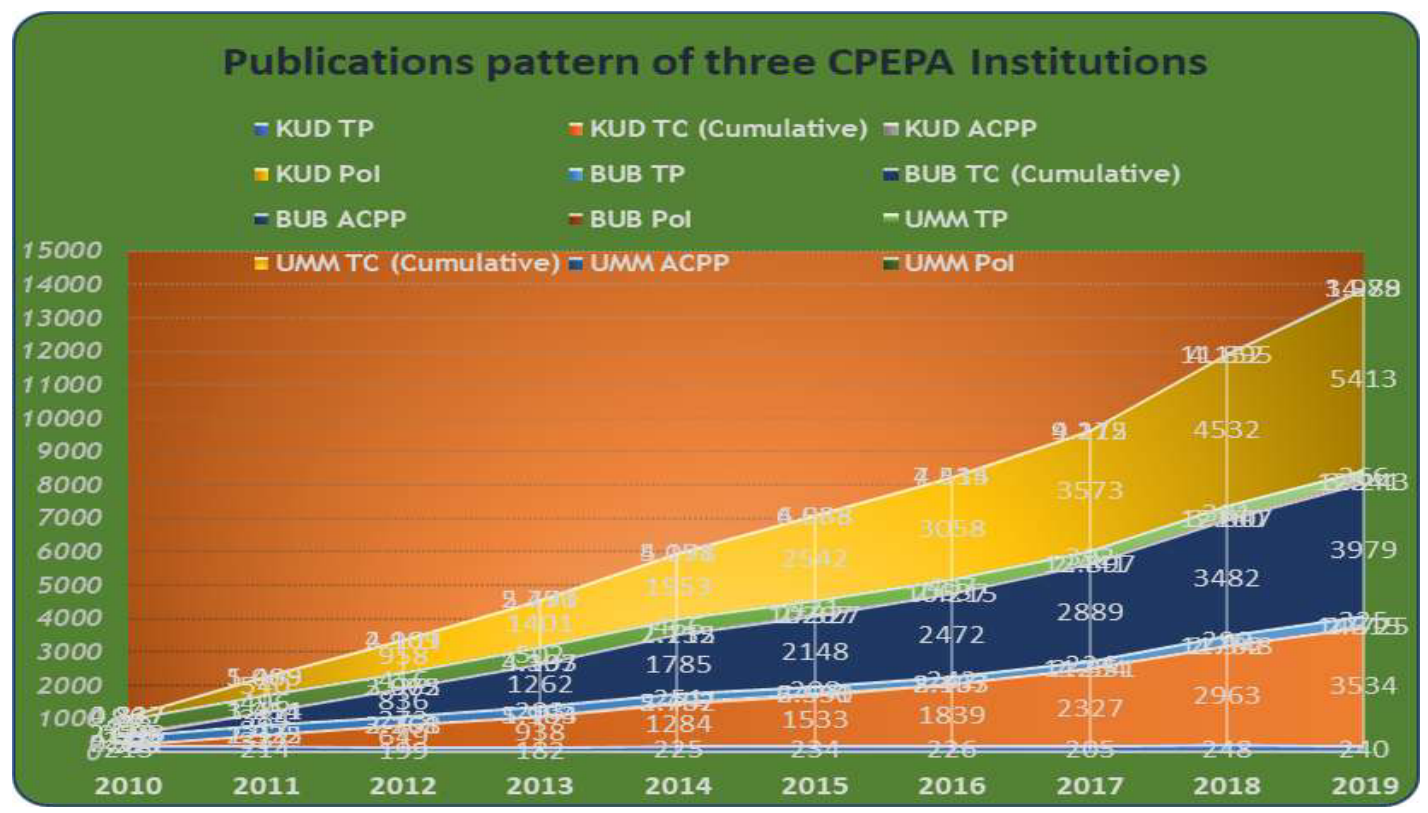

Figure 2. Publications pattern of three CPEPA Institutions

output. Data presented in Table 2 and Figure 2 indicates that the output of the three CPEPA institutions has grown continuously during the period of study.

\subsection{Channels Used for Communicating}

The channels used for communicating three CPEPA institutions' research publications published include articles published in the journals, conference papers, book chapters, reviews, data papers, notes, erratum, editorial materials, and others. This study has observed a total of 8953 publications. It has been observed from table $3 \&$ figure 3 , there are many communicating channels are used by scientists to publish their research articles. The majority of publications are published in Journal articles i.e. 7211 (81\%), followed by Conference Paper 1118 (1.24\%) publications, $245(0.27 \%)$ papers published as book Chapter, 173 are published as Review and less than $1 \%$ of publications are published in other communication channels.

Table 3. Channels Used for Communicating

\begin{tabular}{|l|l|}
\hline Document Type & No of Pub \\
\hline Article & 7211 \\
Conference Paper & 1118 \\
Book Chapter & 245 \\
Review & 173 \\
Data Paper & 68 \\
Note & 33 \\
Erratum & 29 \\
Editorial & 27 \\
Letter & 19 \\
Book & 17 \\
Short Survey & 10 \\
Undefined & 3 \\
\hline
\end{tabular}




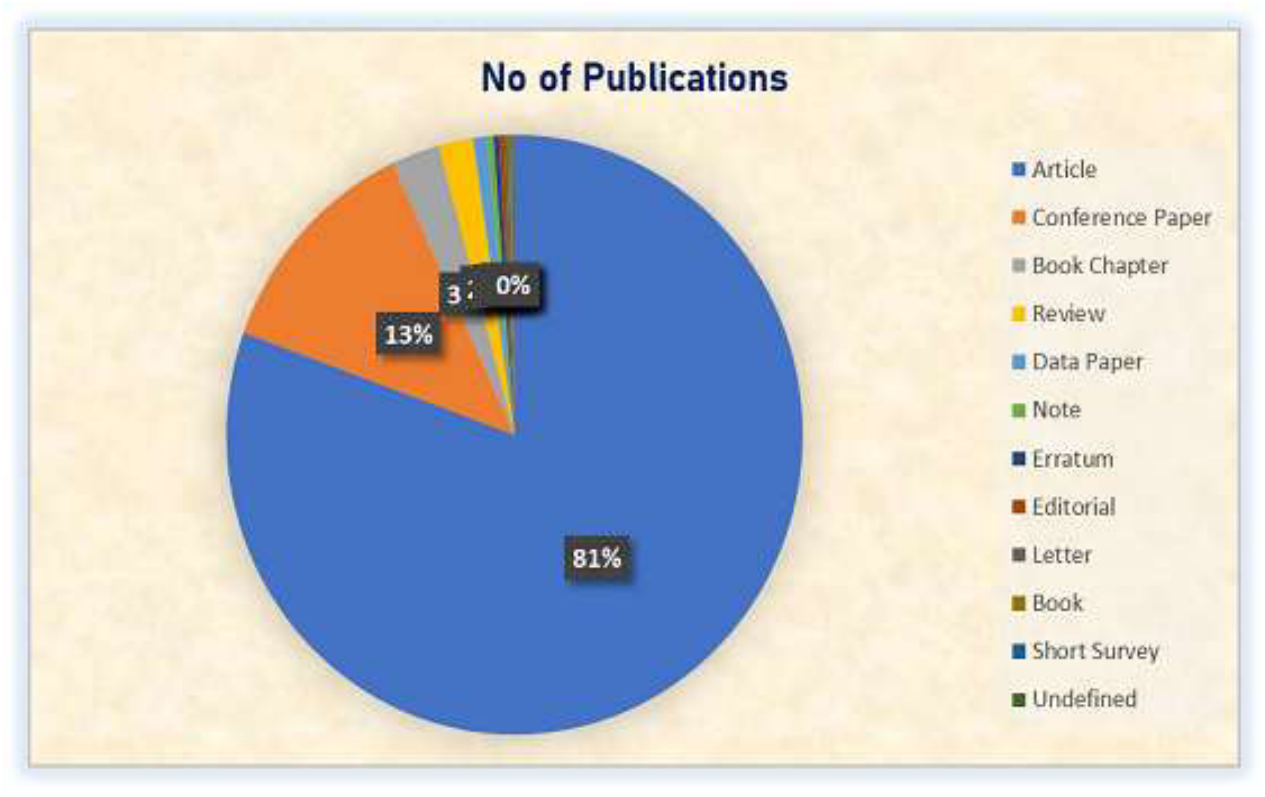

Figure 3. Channels Used for Communicating

\subsection{Most Preferred Subject/ Research Areas}

It is observed from table 4 \& figure 4 , Chemistry has been identified as the three high priority research area of were published in CPEPA institutions research with each contributing publication, followed by Physical and astronomy published 2043 publications, Materials Science published 1763 papers, Biochemistry, Genetics, and Molecular Biology published 1458 papers, Engineering subject published 1249 papers, Agricultural and Biological Sciences published 1033 papers, Pharmacology, Toxicology and Pharmaceutics published 1066 papers, Computer Science published 832 papers, Mathematics published726 papers, Medicine papers published 692 papers, etc.

Table 4. Most Preferred Subject/ Research Areas

\begin{tabular}{|l|l|}
\hline Subject Area & Publications \\
\hline Chemistry & 2823 \\
Physics and Astronomy & 2049 \\
Materials Science & 1763 \\
Biochemistry, Genetics and Molecular Biology & 1458 \\
Engineering & 1249 \\
Agricultural and Biological Sciences & 1033 \\
Pharmacology, Toxicology and Pharmaceutics & 1006 \\
Computer Science & 832 \\
Mathematics & 726 \\
Chemical Engineering & 692 \\
Medicine & 692 \\
Environmental Science & 591 \\
\hline
\end{tabular}




\begin{tabular}{|l|c|}
\hline Social Sciences & 310 \\
Immunology and Microbiology & 266 \\
Energy & 231 \\
Earth and Planetary Sciences & 199 \\
Multidisciplinary & 180 \\
Psychology & 117 \\
Arts and Humanities & 101 \\
Business, Management and Accounting & 73 \\
\hline
\end{tabular}

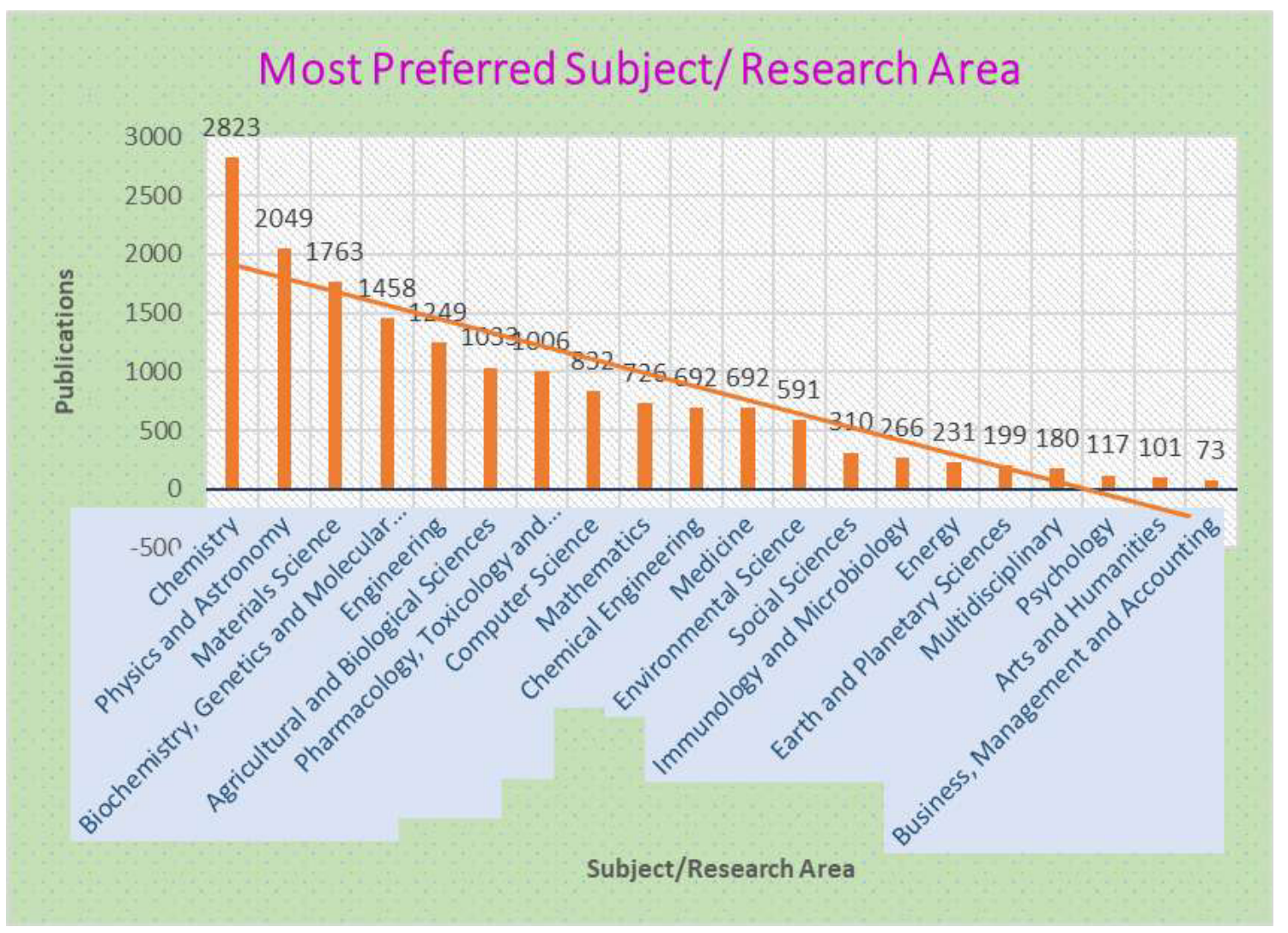

Figure 4. Most preferred subject/research areas

\subsection{Most Productive Authors and Affiliations}

The most productive authors of CPEPA institutions in Karnataka are listed in table 5 \& figure 5 . It is worth to note that the Yathirajan H S; UMM top of the list by contributing 355 papers, 1417 citations with $17 \mathrm{~h}$-index, followed by Lokanath N K; UMM contributed 213 papers with 820 citations and having 12 h-index and Jasinski J P; Keene State College, USA 201 papers with 561 citations and having $8 \mathrm{~h}$-index respectively. Rangappa K S; UMM stand first in $\mathrm{g}$ index 38, followed by Nandibewoor S T; KUD with $\mathrm{g}$ index 34 and Yathirajan $\mathrm{H} \mathrm{S}$ with $\mathrm{g}$ index 24 ranked second and third respectively. The majority of most productive authors belong to UMM (10), followed by BUB with 3 authors; and 3 foreign authors got placed in top 20 list.

\subsection{Most Productive Sources}

Table 6 \& figure 6 presents a list of journals used by the faculties, researchers, and scientists of the CPEPA institutions in Karnataka. Among the various scientific communication journals, it is found that the ACTA Crystallographica Section E: Struc- 
ture Reports Online (USA) the highest number of publications i.e. 482 and 1,285 citations, followed by AIP Conference Proceedings (USA) with 266 publications and 239 citations, Spectrochimica Acta - Part A: Molecular and Biomolecular Spectroscopy (Netherlands) with 95 publications and 1,740 citations, ACTA Crystallographica Section E: Crystallographic Communications (United Kingdom), Journal of Molecular Structure (Netherlands) with 76 publications and 112 citations, International Journal of Pharma and Bio Sciences (India) with 73 publications and 156 citations. It is noted from the table that European Journal of Medicinal Chemistry (France), has received the highest number of citations 1995 with 28 h-index among the list; this retrieves the excellence of the journal and out of the 8953 papers, $1813(20.25 \%)$ appears in the top 20 list.

Table 5. Most productive authors

\begin{tabular}{|c|c|c|c|c|c|c|}
\hline Author & Institution & NP & TC & h_index & g_index & m_index \\
\hline Yathirajan H S & UMM & 355 & 1417 & 17 & 24 & 1.545 \\
\hline Lokanath N K & UMM & 213 & 820 & 12 & 19 & 1.333 \\
\hline Jasinski J P & Keene State College, USA & 201 & 561 & 8 & 13 & 0.727 \\
\hline Rangappa K S & UMM & 191 & 2687 & 27 & 38 & 2.455 \\
\hline Narayana B & Mangalore University, Mangalore & 182 & 892 & 14 & 21 & 1.273 \\
\hline Venugopal K R & BUB & 172 & 572 & 9 & 19 & 0.818 \\
\hline Nandibewoor S T & KUD & 152 & 1677 & 21 & 34 & 1.909 \\
\hline Basavaiah K & UMM & 128 & 506 & 10 & 12 & 0.909 \\
\hline Byrappa K & UMM & 112 & 1037 & 20 & 27 & 1.818 \\
\hline Sureshbabu V V & BUB & 104 & 940 & 18 & 24 & 1.636 \\
\hline Naveen S & UMM & 99 & 553 & 13 & 20 & 1.182 \\
\hline Patnaik L M & IISc, Bangalore & 96 & 345 & 9 & 15 & 0.818 \\
\hline Guru D S & UMM & 95 & 455 & 11 & 18 & 1.000 \\
\hline Murthy H N & KUD & 92 & 1462 & 19 & 35 & 1.727 \\
\hline Shivakumara I S & BUB & 90 & 905 & 16 & 23 & 1.455 \\
\hline Butcher R J & Howard University, USA & 79 & 247 & 7 & 9 & 0.636 \\
\hline Girish K S & UMM & 79 & 1518 & 23 & 34 & 2.091 \\
\hline Kaur M & Keene State College, USA & 78 & 222 & 7 & 11 & 0.778 \\
\hline Somashekar R & UMM & 78 & 366 & 9 & 16 & 0.818 \\
\hline Chandraju S & UMM & 77 & 312 & 10 & 12 & 0.909 \\
\hline
\end{tabular}

\subsection{Most Cited Papers}

The most cited papers of CPEPA of Karnataka are listed in table 7 (Madhu \& Kannappanavar, 2020). The paper "Review on Modified TiO2 Photocatalysis under UV/Visible Light: Selected Results and Related Mechanisms on Interfacial Charge Carrier Transfer Dynamics by S. Girish Kumar and L. Gomathi Devi" has cited 1277 times with 127.7 TCPY followed by "Emissive 


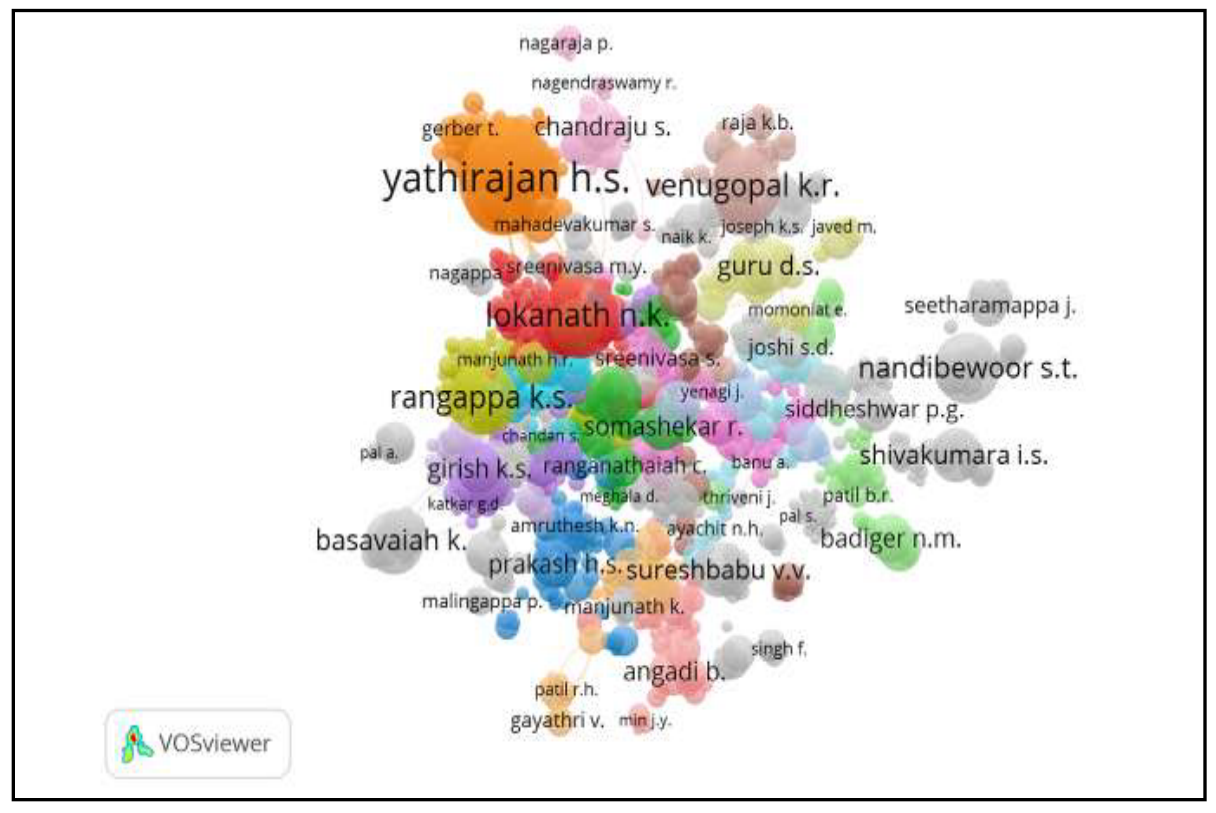

Figure 5. Co- author's network

Table 6. Most productive authors

\begin{tabular}{|c|c|c|c|c|c|}
\hline Source & $\mathbf{T P}$ & TC & h_index & g_index & m_index \\
\hline ACTA Crystallographica Section E: Structure Reports Online & 482 & 1285 & 11 & 18 & 1.000 \\
\hline AIP Conference Proceedings & 266 & 239 & 5 & 7 & 0.455 \\
\hline $\begin{array}{l}\text { Spectrochimica ACTA - Part A: Molecular and Biomolecular } \\
\text { Spectroscopy }\end{array}$ & 95 & 1740 & 27 & 37 & 2.455 \\
\hline $\begin{array}{l}\text { ACTA Crystallographica Section E: Crystallographic Commu- } \\
\text { nications }\end{array}$ & 76 & 112 & 5 & 6 & 0.833 \\
\hline Journal of Molecular Structure & 76 & 751 & 15 & 21 & 1.364 \\
\hline International Journal of Pharma and Bio Sciences & 73 & 156 & 7 & 8 & 0.636 \\
\hline International Journal of Pharmacy and Pharmaceutical Sciences & 70 & 420 & 12 & 16 & 1.091 \\
\hline Chemical Data Collections & 68 & 224 & 7 & 10 & 1.400 \\
\hline Synthetic Communications & 59 & 442 & 12 & 17 & 1.091 \\
\hline RSC Advances & 56 & 1003 & 20 & 27 & 2.500 \\
\hline Molecular Crystals and Liquid Crystals & 53 & 200 & 8 & 11 & 0.727 \\
\hline $\begin{array}{l}\text { Advanced Studies in Contemporary Mathematics } \\
\text { (KYUNGSHANG) }\end{array}$ & 52 & 32 & 4 & 4 & 0.364 \\
\hline Advances in Intelligent Systems and Computing & 51 & 56 & 4 & 4 & 0.500 \\
\hline
\end{tabular}




\begin{tabular}{|l|l|l|l|l|l|}
\hline Communications in Computer and Information Science & 51 & 86 & 5 & 8 & 0.455 \\
European Journal of Medicinal Chemistry & 50 & 1995 & 28 & 44 & 2.545 \\
International Journal of Earth Sciences and Engineering & 50 & 21 & 2 & 3 & 0.182 \\
DER Pharma Chemica & 49 & 193 & 8 & 12 & 0.800 \\
Tetrahedron Letters & 47 & 763 & 17 & 25 & 1.545 \\
Nature Environment and Pollution Technology & 46 & 43 & 4 & 5 & 0.364 \\
Chemistryselect & 43 & 188 & 7 & 8 & 1.400 \\
\hline
\end{tabular}

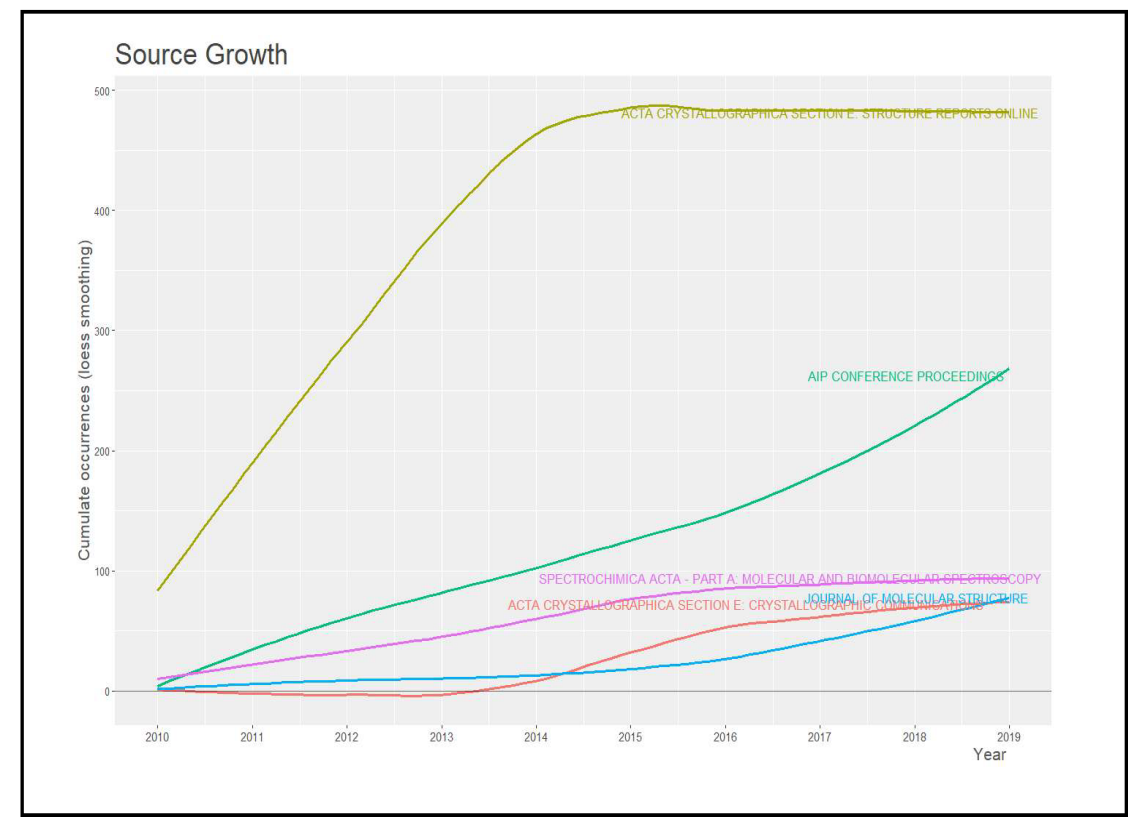

Figure 6. Source growth

ZnO-graphene quantum dots for white-light-emitting diodes by Dong Ick Son, Byoung Wook Kwon, Dong Hee Park, WonSeon Seo, Yeonjin Yi, Basavaraj Angadi, Chang-Lyoul Lee \& Won Kook Choi" with 509 citations and 56.556 TCPY and "A review on non metal ion doped titania for the photocatalytic degradation of organic pollutants under UV/solar light: Role of photogenerated charge carrier dynamics in enhancing the activity by L Gomathi Devi \& R.Kavitha" with 377 citations and 47.125 TCPY. 4 papers have 200 and more citations and 13 papers have more than 100 citations. Figure 7 shows the most cited documents network.

Table 7. Most cited papers

\begin{tabular}{|c|c|c|c|}
\hline Paper & DOI & TC & TCPY \\
\hline KUMAR S G, 2011, J PHYS CHEM A & $10.1021 / j p 204364 a$ & 1277 & 127.700 \\
\hline SON DI, 2012, NAT NANOTECHNOL & $10.1038 /$ nnano. 2012.71 & 509 & 56.556 \\
\hline DEVI LG, 2013, APPL CATAL B ENVIRON & 10.1016/j.apcatb.2013.04.035 & 377 & 47.125 \\
\hline BHAT R, 2010, COMPR REV FOOD SCI FOOD SAF & 10.1111/j.1541-4337.2009.00094.x & 278 & 25.273 \\
\hline
\end{tabular}




\begin{tabular}{|c|c|c|c|}
\hline MURTHY HN, 2014, PLANT CELL TISSUE ORGAN CULT & $10.1007 / \mathrm{s} 11240-014-0467-7$ & 241 & 34.429 \\
\hline KARIGAR CS, 2011, ENZYME RES & $10.4061 / 2011 / 805187$ & 215 & 21.500 \\
\hline ACHAR KCS, 2010, EUR J MED CHEM & 10.1016/j.ejmech.2010.01.029 & 204 & 18.546 \\
\hline REDDY AJ, 2011, J ALLOYS COMPD & 10.1016/j.jallcom.2011.02.043 & 189 & 18.900 \\
\hline BARH D, 2010, CURR ONCOL & 10.3747/co.v17i1.356 & 185 & 16.818 \\
\hline JAYANANDA M, 2013, PRECAMBRIAN RES & 10.1016/j.precamres.2012.05.002 & 182 & 22.750 \\
\hline DEVI LG, 2016, APPL SURF SCI & 10.1016/j.apsusc.2015.11.016 & 180 & 36.000 \\
\hline VAJRAVELU K, 2011, INT J THERM SCI & 10.1016/j.ijthermalsci.2011.01.008 & 177 & 17.700 \\
\hline LAMBERT NM, 2013, PERS SOC PSYCHOL BULL & $10.1177 / 0146167213499186$ & 170 & 21.250 \\
\hline SHINGALAPUR RV, 2010, EUR J MED CHEM & 10.1016/j.ejmech.2010.01.007 & 157 & 14.273 \\
\hline NAIK PN, 2010, J PHOTOCHEM PHOTOBIOL B BIOL & 10.1016/j.jphotobiol.2010.05.014 & 153 & 13.909 \\
\hline NAGENDRAPPA G, 2011, APPL CLAY SCI & 10.1016/j.clay.2010.09.016 & 149 & 14.900 \\
\hline DEVI LG, 2010, J MOL CATAL A CHEM & 10.1016/j.molcata.2010.05.021 & 140 & 12.727 \\
\hline GAO W, 2018, INF SCI & 10.1016/j.ins.2018.07.049 & 138 & 46.000 \\
\hline PARK A, 2010, TISSUE ENG PART A & 10.1089/ten.tea.2009.0710 & 125 & 11.364 \\
\hline GOMATHI DEVI L, 2014, RSC ADV & $10.1039 / \mathrm{c} 4 \mathrm{ra} 03291 \mathrm{~h}$ & 119 & 17.000 \\
\hline
\end{tabular}

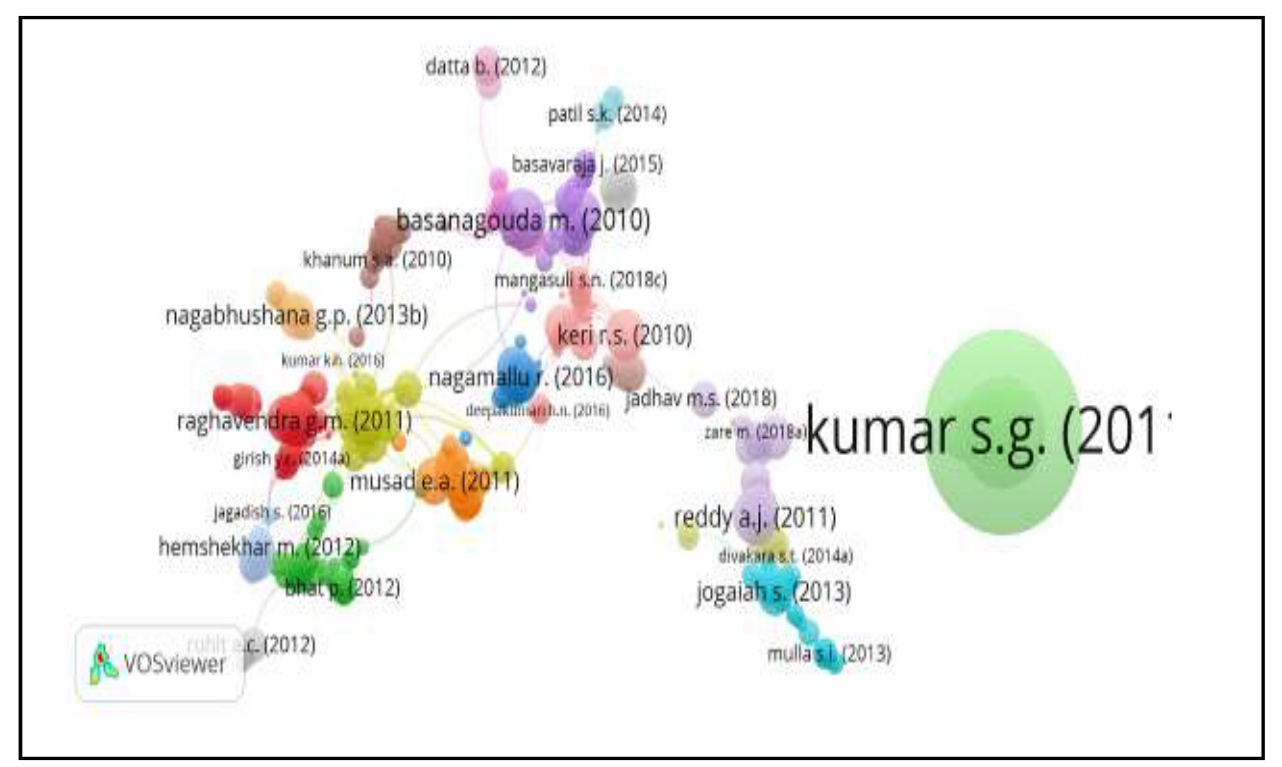

Figure 7. Documents citation network

\subsection{Country Collaboration}

Research collaboration and co-authorship is a growing phenomenon in research and development (Noruzi \& Abdekhoda, 2013) (Noruzi \& Abdekhoda, 2014). Table 8 shows the distribution of international collaboration; the three CPEPA's of Karnataka together have published 2114 international collaborative papers. The researchers of these CPEPA's of Karnataka together have collaborated with 19 countries of the world during $2010-2019$. The highest research collaboration of these CPEPA's of 
Table 8. Collaboration with other countries

\begin{tabular}{|c|c|c|c|}
\hline Country & $\mathbf{T P}$ & TC & ACPA \\
\hline USA & 645 & 2136 & 08.18 \\
\hline United Kingdom & 189 & 504 & 13.62 \\
\hline Korea & 167 & 1864 & 19.02 \\
\hline China & 149 & 264 & 11.00 \\
\hline Malaysia & 120 & 524 & 19.41 \\
\hline Japan & 119 & 325 & 17.11 \\
\hline Iran & 114 & 411 & 09.56 \\
\hline Saudi Arabia & 99 & 63 & 15.75 \\
\hline Germany & 84 & 404 & 21.26 \\
\hline South Africa & 81 & 166 & 03.32 \\
\hline Turkey & 76 & 178 & 07.74 \\
\hline Australia & 66 & 72 & 12.00 \\
\hline Singapore & 60 & 79 & 09.88 \\
\hline Poland & 48 & 139 & 03.76 \\
\hline Netherlands & 30 & 179 & 29.83 \\
\hline Hong Kong & 25 & 134 & 14.89 \\
\hline Brazil & 22 & 70 & 23.33 \\
\hline Ireland & 11 & 71 & 71.00 \\
\hline Qatar & 9 & 43 & 21.50 \\
\hline
\end{tabular}

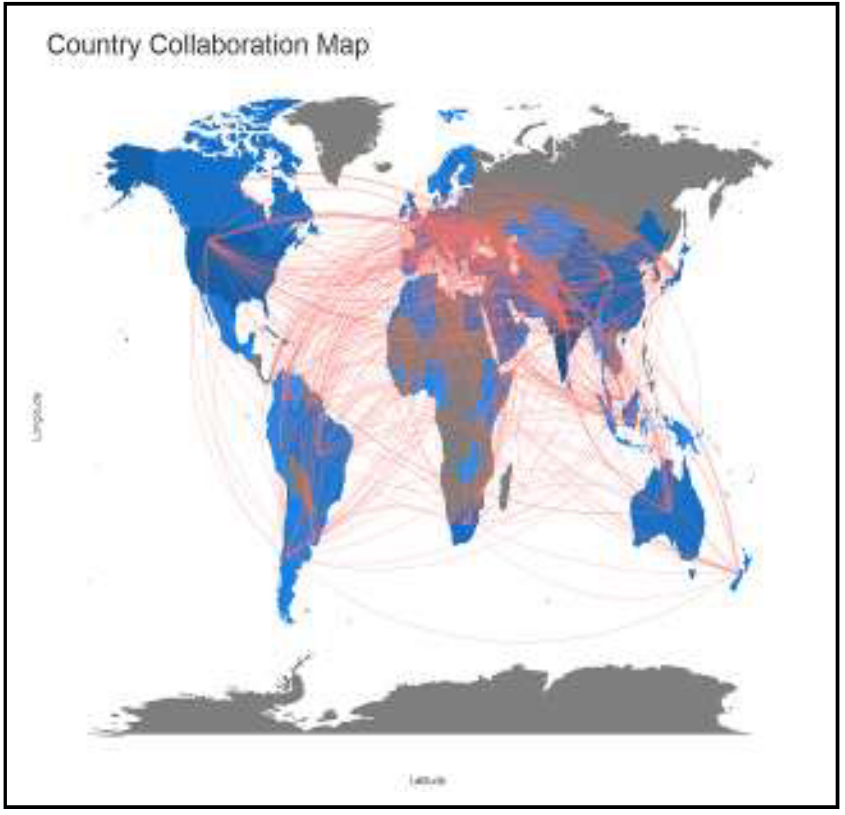

Figure 8. Country collaboration map 
Karnataka has been found with the USA (645 papers; 2136 TC) followed by the UK with 189 papers and Korea with 167 papers. Among these collaborative countries, only two countries have produced $4000(52.45 \%)$ total citations. Fig $8 \&$ fig 9 shows the country collaboration map and Co-authorship-Countries network.

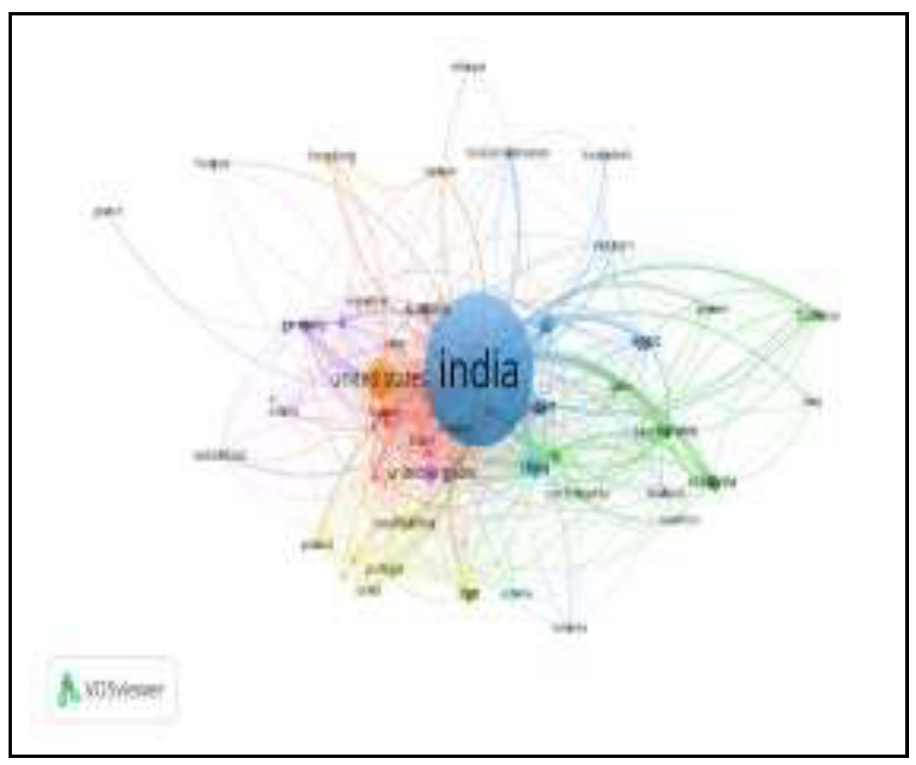

Figure 9. Co-authorship Countries network

\subsection{Most Used Keywords}

The keywords co-occurrence network map, the top 20 keywords of these three CPEPA's of Karnataka publications, the keywords density visualization map, and the keywords timeline view will be shown (Figure 10). Keywords co-occurrence can effectively reflect the research hotspots in the discipline fields, providing secondary support for scientific research. In all 8953 publications, we got 38347 keywords. The keyword co-occurrence network of CPEPA's of Karnataka was constructed by the VOSviewer software. The nodes with the same colour belong to a cluster. VOSviewer divided the keywords of CPEPA's of Karnataka publications into 5 clusters. The keyword 'article' is used 2093 times followed by 'Nonhuman' 1146 times, 'Controlled Study' 1129 times, and 'Unclassified Drug' 1020 times. Four keywords 'Human', 'Animals', 'Priority Journal', 'Humans' are occurred between 500 to 757 times, and the remaining 12 keywords occurred between 294 to 487 times. The top 20 keywords with their frequencies are shown in Table 9.

Table 9. Keywords analysis

\begin{tabular}{|l|l|}
\hline Keyword & No of Times \\
\hline Article & 2093 \\
Nonhuman & 1146 \\
Controlled Study & 1129 \\
Unclassified Drug & 1020 \\
Human & 757 \\
Animals & 537 \\
Priority Journal & 525 \\
Humans & 500 \\
Chemistry & 487 \\
India & 487 \\
\hline
\end{tabular}




\begin{tabular}{|l|l|}
\hline X Ray Diffraction & 444 \\
Metabolism & 438 \\
Male & 432 \\
Drug Synthesis & 414 \\
Female & 385 \\
Animal & 384 \\
Crystal Structure & 373 \\
Animal Experiment & 340 \\
In Vitro Study & 313 \\
Scanning Electron Microscopy & 294 \\
\hline
\end{tabular}

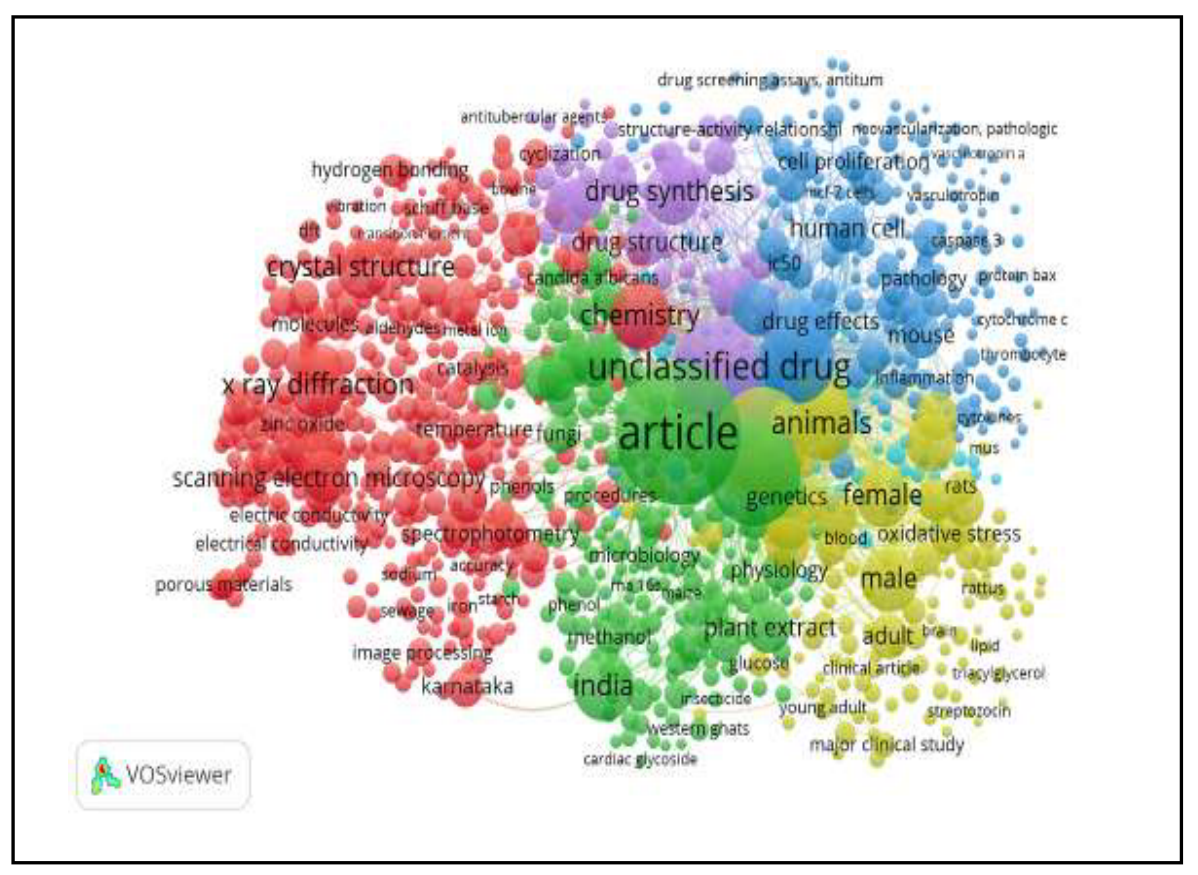

Figure 10. All keywords co-occurrence network

\section{Discussion and Conclusion}

This study measured research productivity and visualization on CPEPA's of Karnataka publications. The analysis focused on significant indicators of research productivity, distribution of publications, and most productive authors and keyword analysis. The Scientific productivity of institutions/ universities can be measured by the counting of research publications in the journals and proceedings, and the number of citations received in those publications. Although the leading faculty members of universities contribute much of their work in journals covered by Scopus, a significant number of publications of universities appear in national and other international journals, which are not covered by the Scopus.

The results presented that UMM performs top on most of the indicators among the CPEPA's of Karnataka and the other two also performed reasonably well in some indicators.

The authors think that the CPEPA's in Karnataka state should pay special attention to develop a suitable research policy. As the CPEPA's in Karnataka state receive funds from UGC (University Grants Commission), these institutions should utilize funds for improving research facilities and availing equipment for scientific productivity. To increase citations and visibility of 
publications from universities and to improve their research impact, universities should establish repositories at the regional or institutional level.

The Indian government contributes about one-fourth of total governmental expenditure on education in India, though it has a key share in research funding. The data points towards the fact that organized and planned efforts by the governments are essential in the higher education sector to progress the overall environment in which Indian higher education institutions are working at present. In the modern time of a globalized world and knowledge-based economies, it becomes more significant that we initiate an efficient and honest effort to progress the Indian higher education system, particularly the multidisciplinary universities.

\section{References}

[1] Aria, M., Cuccurullo, C. (2017). bibliometrix: An R-tool for comprehensive science mapping analysis. Journal of Informetrics, 11(4), 959-975. https://doi.org/10.1016/j.joi.2017.08.007

[2] Banshal, S. K., Solanki, T., Singh, V. K. (2018). Research performance of the National Institutes of Technology in India. Current Science, 115(11), 2025-2036. https://doi.org/10.18520/cs/v115/i11/2025-2036

[3] Basu, A., Banshal, S. K., Singhal, K., Singh, V. K. (2016). Designing a Composite Index for research performance evaluation at the national or regional level: ranking Central Universities in India. Scientometrics, 107 (3), 1171-1193. https://doi.org/ $10.1007 / \mathrm{s} 11192-016-1935-0$

[4] Das, T. K. (2019). Bibliometric analysis of research publications of IITs: A study based on Scopus. Journal of Academic Librarianship, 20 (3), 105-123.

[5] García-García, P., López-Muñoz, F., Callejo, J., Martín-Águeda, B., \& Álamo, C. (2005). Evolution of Spanish scientific production in international obstetrics and gynecology journals during the period 1986-2002. European Journal of Obstetrics and Gynecology and Reproductive Biology, 123 (2), 150-156. https://doi.org/10.1016/j.ejogrb.2005.06.039

[6] Gourikeremath, G.N., Kumbar, B., Hadagali, G. S., Hiremath, R. (2015). Scientific Productivity of Universities Accredited with Universities with Potential for Excellence (UPE) status in India. Journal of Advances in Library and Information Science, $4(2), 135-146$.

[7] Gourikeremath, Gouri., Hiremath, R. S. (2020). A Comparative Study of University of Mysore and Karnatak University in Science/ : Research Output and Citation Impact During 2002-16. 56(2), 75-83.

[8] Kappi, M. (2019). Bibliometric Analysis of the Research Output of Kuvempu University's Publication in ISI Web of Science during 1990 - 2019. Library Philosophy and Practice (e-Journal). https://digitalcommons.unl.edu/libphilprac/3632

[9] Kappi, M., Dr. Chaman Sab, M, M. B., Bagalkoti, D. V. T. (2020). Research Productivity of NIRF 2020 Top Indian Law Institutions. In D. P. Rai, D. A. Singh, D. Arjun, S. Prasad, \& D. V. Bansal (Eds.), Changing Dimensions of Education and Librarianship during COVID-19 (p 48-68). AKB Publication. akbpublication.com

[10] Kumar, A., Tiwari, S., Chauhan, A. K., Ahirwar, R. (2019). Impact of NIRF on research publications: A study on top 20 (ranked) Indian Universities. COLLNET Journal of Scientometrics and Information Management, 13(2), 219-229. https://doi.org/ 10.1080/09737766.2020.1741194

[11] Kumar, S., Senthilkumar, R. (2019). Scientometric mapping of research output of NIRF first ranked institute of India: IISc, Bangalore. Library Philosophy and Practice, 2019.

[12] Madhu, S., Kannappanavar, B. U. (2020). Digital Commons @ University of Nebraska - Lincoln Bio-bibliometric Study of Prof. P Balaram contributions in the field of Bio-organic Chemistry and Molecular Biophysics. Library Philosophy and Practice. https://digitalcommons.unl.edu/libphilprac/4349

[13] Marisha, Banshal, S. K., Singh, V. K. (2017). Research performance of central universities in India. Current Science, 112(11), 2198-2207. https://doi.org/10.18520/cs/v112/i11/2198-2207

[14] Noruzi, A., Abdekhoda, M. (2014). Scientometric analysis of Iraqi-Kurdistan universities' scientific productivity. Electronic Library. https://doi.org/10.1108/EL-01-2013-0004

[15] Prathap, G. (2013). Benchmarking research performance of the IITs using Web of Science and Scopus bibliometric databases. Current Science, 105(8), 1134-1137.

[16] Prathap, G. (2014). The performance of research-intensive higher educational institutions in India. Current Science, 107(3), 389-396. https://doi.org/10.18520/cs/v107/i3/389-396

[17] Prathap, G., Gupta, B. M. (2009). Ranking of Indian engineering and technological institutes for their research performance during 1999-2008. Current Science, 97(3), 304-306. 
[18] Prathap, G., Sriram, P. (2017). Mega private universities in India: Prospects and promise for world-class performance. Current Science, 113(11), 2165-2167. https://doi.org/10.18520/cs/v113/i11/2165-2167

[19] Rajan, K. S., Swaminathan, S., Vaidhyasubramaniam, S. (2018). Research output of Indian institutions during 2011-2016: Quality and quantity perspective. Current Science, 114(4), 740-746. https://doi.org/10.18520/cs/v114/i04/740-746

[20] Sangam, S. L., Bagalkoti, V. T. (2015). Rankings of Indian Universities: A Scientometrics Analysis. Proceedings of 10th International CALIBER 2015, March, 182-191.

[21] Sharma, A. K., Dwivedee, B. P., Soni, S., Kapoor, D. N., Patil, V. (2019). Scientometric analysis of biotechnology research output in India during 2008-2017. Library Philosophy and Practice, 2019 (September).

[22] Solanki, T., Uddin, A., Singh, V. K. (2016). Research competitiveness of Indian institutes of science education and research. Current Science, 110(3), 307-310. https://doi.org/10.18520/cs/v110/i3/307-310

[23] UGC CPEPA12. (2011). https://www.ugc.ac.in/pdfnews/2533399_CPEPA12.pdf

[24] Utama, Y. J., Setiyono, B., Jamari, Tauviqirrahman, M., Susanto, H. (2019). Bibliometric Analysis of Publications in the Scopus Database: A Study at Diponegoro University during 2014-2018. E3S Web of Conferences, 125 (2019), 1-5. https:// doi.org/10.1051/e3sconf/201912523001

[25] van Eck, N. J., Waltman, L. (2010). Software survey: VOSviewer, a computer program for bibliometric mapping. Scientometrics, 84(2), 523-538. https://doi.org/10.1007/s11192-009-0146-3 